\title{
Preparation and Characterization of Micro/Nano-emulsions Containing Functional Food Components*
}

\author{
Zheng WANG ${ }^{1,2}$, Marcos A. NEVES ${ }^{1,2}$, Hiroko ISODA ${ }^{1,2}$, Mitsutoshi NAKAJIMA ${ }^{1,2, \dagger}$ \\ ${ }^{1}$ Alliance for Research on North Africa, University of Tsukuba, 1-1-1, Tennodai, Tsukuba, Ibaraki 305-8572, Japan \\ ${ }^{2}$ Faculty of Life and Environmental Sciences, University of Tsukuba, 1-1-1 Tennodai, Tsukuba, Ibaraki 305-8572, Japan
}

\begin{abstract}
Emulsions are dispersions of at least two immiscible liquids, one of which is dispersed as droplets in the other liquid, and stabilized by an emulsifier, such as oil and water. Different types of emulsions can be formulated according to different applications. Emulsions are categorized as simple or multiple type. Oil-in-water $(\mathrm{O} / \mathrm{W})$ and water-in-oil $(\mathrm{W} / \mathrm{O})$ are the simple emulsions, while water-in-oilin-water $(\mathrm{W} / \mathrm{O} / \mathrm{W})$, and oil-in-water-in-oil $(\mathrm{O} / \mathrm{W} / \mathrm{O})$ emulsions are known as multiple emulsions. Droplets of different sizes and the size distribution patterns formed based on different emulsification processes can affect their physicochemical properties. Hence, the droplet size and its distribution may determine the shelf-life stability, rheological properties, color and taste of food emulsions. Micro/ nano-emulsions have been increasingly utilized in the food industry as delivery system carriers that can encapsulate, protect, and deliver lipophilic functional food components, such as bioactive lipids, oil-soluble flavors, vitamins, and nutraceuticals. The application of micro/nano-emulsions has potential advantages in increasing the bioavailability of lipophilic functional food components, modulating the product texture and improving the stability of droplets against aggregation. This article provides an overview of the current status of micro/nano-emulsion containing functional food components, preparations and characterizations, and presents the applications of micro/nanoemulsions in food industry.
\end{abstract}

Keywords: emulsification, micro/nano-emulsion, functional food components, micro/nano device, delivery system

\section{Introduction}

Emulsion can be defined as two immiscible liquids such as oil and water, with one of the liquids dispersed as small droplets in another. One of the immiscible liquids, defined as the disperse phase, is dispersed as small droplets in another liquid, defined as the continuous phase. To form a stable emulsion, a substance with emulsifying property has to be included, such substances are defined as emulsifiers [1]. As the same composition of emulsion, the droplets size and droplet size distribution greatly affect the properties of the emulsion. The stability of emulsions can be improved with small droplet sizes and narrow size distributions. A conventional emulsion typically has a droplet diameter between 0.01 to $100 \mu \mathrm{m}$. It is thermodynamically unstable due to the relatively high interfacial tension associated with the contact between the oil and water phases. A nano-emulsion generally has

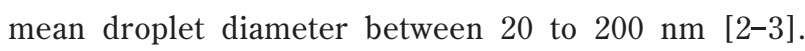

(Received 5 Aug. 2015: accepted 17 Nov. 2015)

$\dagger$ Fax: +81-29-853-5776, E-mail: nakajima.m.fu@u.tsukuba.ac.jp

*This article is based on a study first reported in the FFI journal Vol. 219, No. 4 (2014) with full reference.
Emulsion types can be classified into different groups, such as oil-in-water (O/W), water-in-oil (W/O), and multiple emulsions. $\mathrm{O} / \mathrm{W}$ emulsions consist of oil droplets in a continuous water phase, and W/O emulsions consist of water droplets in a continuous oil phase. Multiple emulsions are more complex systems, and consist of smaller droplets dispersed in larger droplets that are dispersed in a continuous phase. For instance, waterin-oil-in-water $(\mathrm{W} / \mathrm{O} / \mathrm{W})$ emulsion consists of internal water droplets dispersed in larger oil droplets, which are themselves dispersed in an external continuous aqueous phase. On the other hand, an oil-water-in-oil (O/W/O) emulsion consists of oil droplets dispersed in water droplets, which are themselves dispersed in a continuous oil phase [4]. Nano-emulsion based food delivery systems (FDS) and drug delivery systems (DDS) have been applied in food, pharmaceutical and cosmetic fields. In the human digestive system, ingested food is broken down into small nutrient molecules that can be absorbed into the blood plasma. During the digestion process, most of the nutrients are transported as $\mathrm{O} / \mathrm{W}$ emulsions. In particular, the particle size can be decreased from nano to mixed micelles order in the just before absorp- 
tion. It is considered that high ratio of functional food compounds recovered from mixed micelles may have a high availability. However many of these compounds are unstable to heat, light, and oxygen; also, most of them are water-insoluble. The low solubility of these functional food compounds impairs their bioavailability and limits their use. On the other hand, the formulation of functional food compounds into micro/nano-emulsions is expected to improve their bioavailability. In this article, we present recent trends on the encapsulation of functional food compounds, focusing on the preparation and characterization of micro/nano-emulsion containing functional food components. We also present some applications of micro/nano-emulsions in food and other related industries.

\section{Encapsulation of functional compounds}

In general, there are two methods to produce micro/ nano-emulsions with smaller droplet diameters and narrow size distributions: low- and high-energy input emulsifications. In high-energy emulsification methods, the emulsification is done using mechanical equipment including high-speed mixer, microfluidization, and ultrasonic emulsification. On the other hand, in low-energy emulsification methods, such as membrane emulsification, micro/nano channel emulsification, phase inversion emulsification and so on, the emulsions can be produced based on physicochemical behavior of the emulsifiers. We describe the process for using each approach in detail below. Depending on the methods employed, many types of emulsion systems containing functional com- pounds were prepared, and investigated. Table 1 shows the summary of micro/nano-emulsions containing functional food compounds research and applications [5-17]. Besides, oil-in-water emulsion system using virgin Picholine olive oil, containing high flavonoids such as apigenin, showed higher antiallergenic effect compared with bulk olive oil system [18, 19].

\subsection{High-speed mixer}

High-speed mixers are used worldwide as emulsification devices in laboratory and industry fields. Figure 1 schematically represents details of a commercial highspeed mixer with rotor-stator polytron. The rotor-stator shaft consists of a rotor housed concentrically inside the stator with blades and a stator with different type of slots (vertical or slant). As the rotor rotates, it generates a

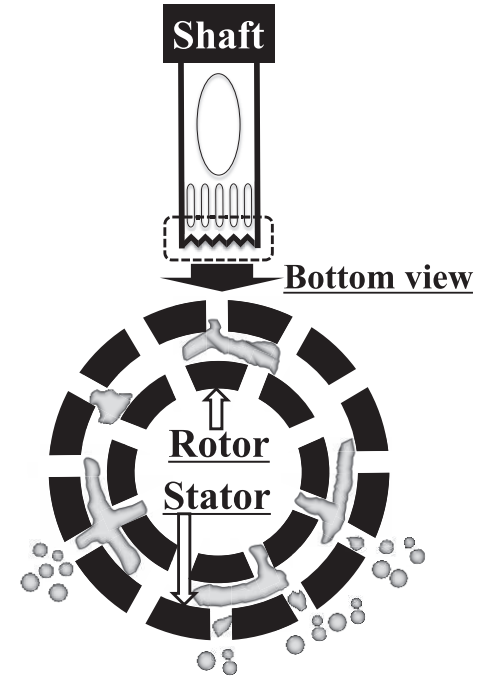

Fig. 1 High-speed mixer (Polytron $\left.{ }^{\circledR}\right)$.

Table 1 Summary of research and application for micro/nano-emulsion loaded functional compounds.

\begin{tabular}{lllc}
\hline Functional Compounds & \multicolumn{1}{c}{ Benefits } & \multicolumn{1}{c}{ Applications } & Reference \\
\hline$\alpha$-Tocopherol & Antioxidant & Medicine/Food & 5 \\
$\beta$-Carotene & Antioxidants/Vitamin A precursor & Food color & 6 \\
Curcumin & Antioxidant/Anti-inflammatory/ & Food color & 7 \\
Anticancer & Cholesterol absorption inhibitor & Medicine/Cosmetic/Food additive & 8 \\
Lycopene & Antioxidant/Anticancer & Food color & 9 \\
Lidocaine & Local anesthetic/Antiarrhythmic drug & Medicine & 10 \\
Itraconazole & Antifungal & Medicine & 11 \\
Carbamazepine & Anticonvulsant & Medicine & 12 \\
Quercetin & Antioxidants/Anti-inflammatory & Medicine/Food & 13 \\
Cisplatin & Anticancer & Medicine & 14 \\
Thalidomide & Immunomodulatory agent & Medicine & 15 \\
Polyunsaturated fatty & Anti-inflammatory & Food/Medicine & 16 \\
acids (PUFA) & Antioxidant & Food & 17 \\
Oleuropein & &
\end{tabular}


lower pressure to take the liquid in and out of the assembly, thereby resulting in cavitation and emulsification. High-speed mixer has processing capacity with broad ranges, typically from 0.005 to $10 \mathrm{~L} / \mathrm{h}$ can be used for laboratory scale, and 10 to $5000 \mathrm{~L} / \mathrm{h}$ are often used for industrial scale. The droplet diameters can be decreased with longer emulsification times and higher rotation speeds. However, the higher rotation speeds can also generate heat, therefore the temperature control is needed for some functional compounds that are sensitive to temperature [1]. Jafari et al. prepared emulsions containing essential oil by high-speed mixer. The mean droplet diameters were $10 \pm 0.08 \mu \mathrm{m}$ [20].

\subsection{High-pressure emulsification}

A large amount of mechanical energy needed for the formation of micro/nano-emulsion. The free energy required $(\Delta G)$ for the area of oil-water interface increase $(\Delta A)$ can be given by the following equation.

$$
\Delta G=\gamma \Delta A
$$

where $\gamma$ is the interfacial tension. For example, to prepare an $\mathrm{O} / \mathrm{W}$ emulsion as $\gamma$ is $10 \mathrm{mN} / \mathrm{m}$ when the volume fraction of oil is 0.1 and the radius is $0.1 \mu \mathrm{m}$, the increased surface energy is calculated as $30 \mathrm{~kJ} / \mathrm{m}^{3}$. Actually, small size of droplets can be formulated by oil droplet disintegration that requires a large pressure gradient, usually 1000 times of the normal value (30 MJ/ $\mathrm{m}^{3}$ ), to prepare such an emulsion. Moreover, the flow of a liquid through high shear rates results in large amount of energy dissipation, due to the friction losses. The excess energy is converted into heat, this is why cooling is required during emulsification. The effects of number of passes on emulsion temperature for different pressure levels are shown in Fig. 2. Seemingly, Fig. 3 shows the effect of emulsifying pressure on emulsion temperature at the exit of the valve. Temperature rises as the number of pass increases at the same pressure. Moreover, the temperature increases to around $80^{\circ} \mathrm{C}$ when the pressure is $300 \mathrm{MPa}[21,22]$.

High-pressure homogenization is the widely used method for preparing micro/nano-emulsions. Highpressure homogenization is extensively used both in laboratories and as well as in industries. Typical, often utilized high-pressure homogenizers are high-pressure valve homogenizer (HPH) and Microfluidizer. A HPH consists of a piston pump and a narrow gap, where the maximum operating pressure is $350 \mathrm{MPa}$. Droplet breakup occurs within the region of valve gap and in the

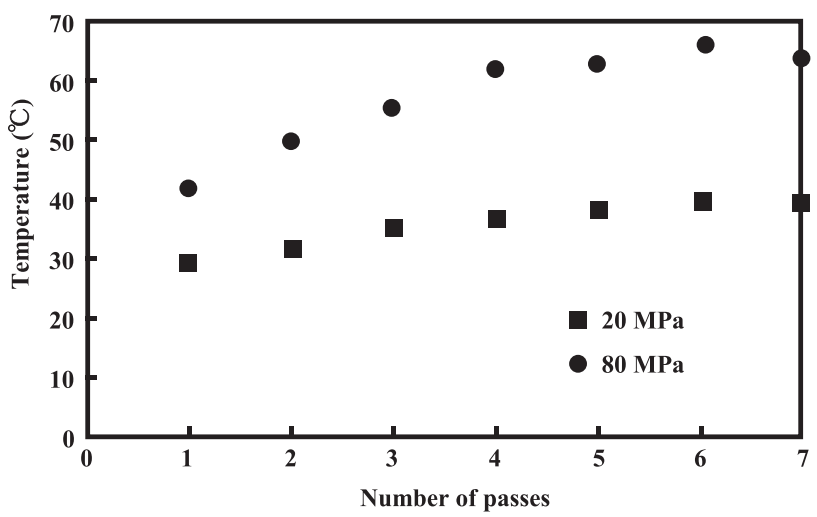

Fig. 2 Effects of number of passes on the temperature of emulsions, for different operating pressure [21].

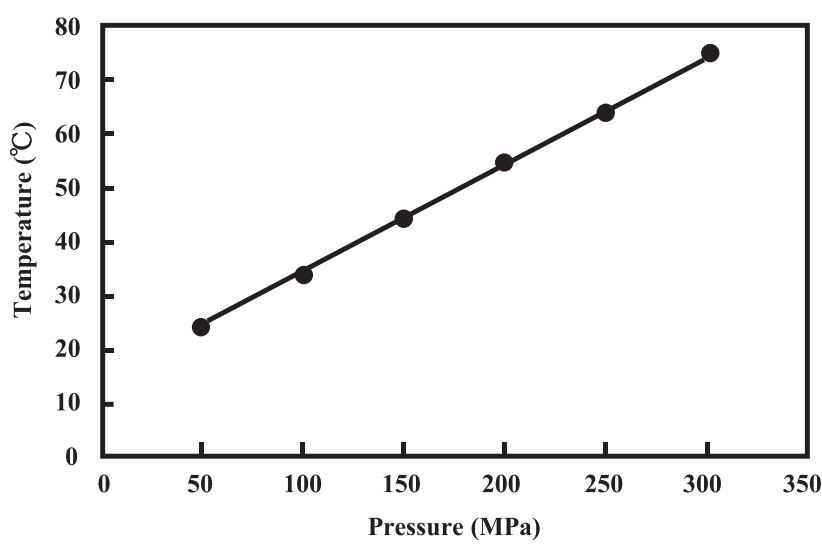

Fig. 3 Effect of pressure on temperature at the exit of the valve [22].

jet after the gap (Fig. 4) [23]. Figure 5 shows that an emulsion containing $\beta$-carotene was produced by HPH. Here, $\beta$-carotene was dissolved in medium chain triacylglycerol as a dispersed phase and $10 \%$ of Tween 20 aqueous solution was used as continuous phase. The processing was carried out 3 times for each pressure, and the droplet diameter tended to decrease with the pressure increase [24]. Besides, some factors can lead to the decrease of the droplet diameter such as the increased

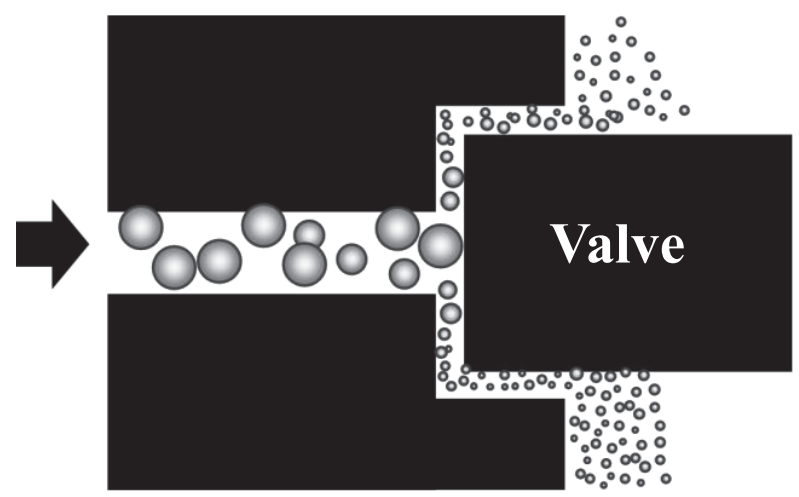

Fig. 4 High-pressure valve homogenizer [23]. 


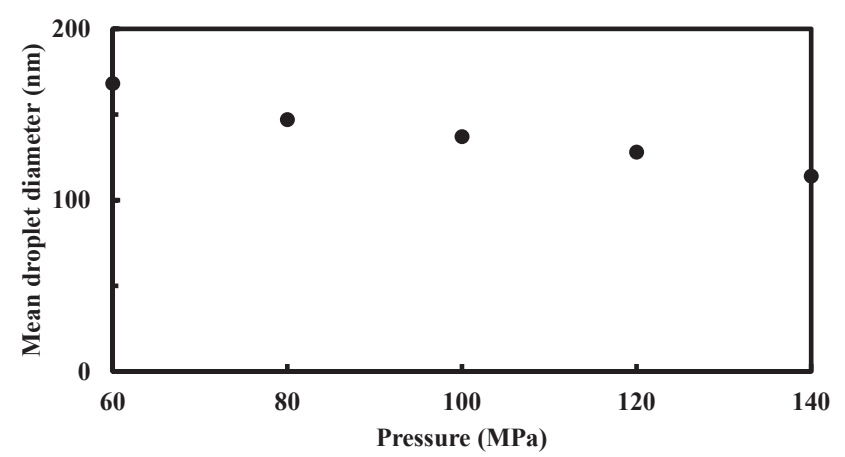

Fig. 5 Preparation of $\beta$-carotene loaded nanoemulsions by high-pressure emulsification [24].

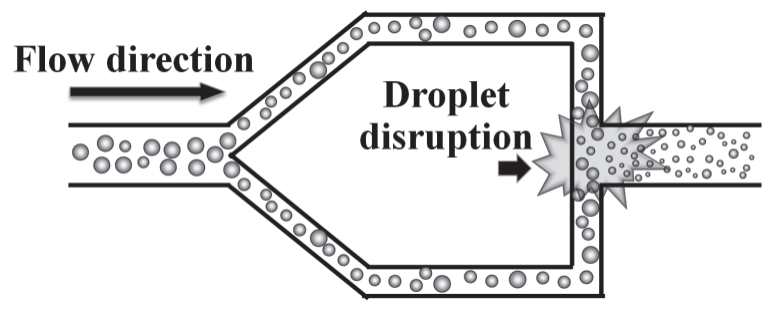

Fig. 6 Schematic representation of Microfluidizer ${ }^{\circledR}$ interaction chamber. number of passes, the decrease of interfacial tension and if the viscosity ratio of disperse phase to continuous phase is between 0.05 and 5 [25]. Table 2 summarizes some references where HPH was used [24, 26-28]. On the other hand, Microfluidizer ${ }^{\circledR}$ comprises of a fluid inlet, a pump, and a chamber with two channels where the fluids are taken into, and then impact with each other (Fig.6). The coarse emulsion is forced into an inlet channel by high pressure and divided into two streams to make an impact force on each other at high velocity in the interaction chamber. The intensive shear force generated in the interaction chamber is highly effective for breaking droplets up and forming $30 \mathrm{~nm}-3 \mu \mathrm{m}$-order micro/nano-emulsions. Table 3 summarizes references related to the emulsion preparation using Microfluidizer [29-35]. The droplet diameter can also be affected by increasing the operating pressure, the number of passes and so on.

\subsection{Ultrasonic emulsification}

Ultrasonic emulsification is also a very effective processing method in the generation and application of

Table 2 An overview of reference on $\mathrm{O} / \mathrm{W}$ nano-emulsion formulation using high-pressure valve homogenizer.

\begin{tabular}{|c|c|c|c|c|}
\hline $\begin{array}{l}\text { Dispersed } \\
\text { Phase }\end{array}$ & $\begin{array}{l}\text { Functional } \\
\text { Compounds }\end{array}$ & Emulsifier* & $\begin{array}{c}\text { Droplet Diameter } \\
(\mathrm{nm})\end{array}$ & Reference \\
\hline $\mathrm{MCT}$ & $\beta$-Carotene & Tween $20,40,60,80$ & $114-178$ & 24 \\
\hline MCT & $\beta$-Carotene & Tween 20, ML750, WPI, Modified starch & $115-303$ & 26 \\
\hline $\mathrm{MCT}$ & Curcumin & Tween 20 & $82-184$ & 27 \\
\hline Olive oil & - & Pluronic ${ }^{\circledR}$ F-68, Phospholipid & $239-274$ & 28 \\
\hline
\end{tabular}

*Tween: Polysorbate

* ML: Decaglycerol monolaurate

*WPI: Whey protein isolate

** MCT: Medium chain triglyceride

Table 3 An overview of references on $\mathrm{O} / \mathrm{W}$ nano-emulsion formulation using Microfluidizer ${ }^{\circledR}$.

\begin{tabular}{lclcc}
\hline \multicolumn{1}{c}{$\begin{array}{c}\text { Dispersed } \\
\text { Phase }\end{array}$} & $\begin{array}{c}\text { Functional } \\
\text { Compounds }\end{array}$ & \multicolumn{1}{c}{ Emulsifier* } & $\begin{array}{c}\text { Droplet } \\
\text { Diameter (nm) }\end{array}$ & Reference \\
\hline$d$-Limonene/Fish oil & - & WPC, WPH, SC, Modified starch & $175-585$ & 29 \\
Peanut oil & - & Tween 80 & $115-303$ & 30 \\
& Coenzyme Q10 & $\begin{array}{l}\text { Non-ionic Surfactant, Lecithin, } \\
\text { Tween 20, } \beta \text {-Lactoglobulin }\end{array}$ & 60 & 31 \\
MCT $^{* *}$ & $\alpha$-Tocopherol & Lecithin & $85-381$ & 32 \\
MCT $^{* *}$ & - & Tween 20, $\beta$-Lactoglobulin & $60-150$ & 33 \\
Corn oil & - & Polyglycerol esters of fatty acids & $180-380$ & 34 \\
Soybean oil & $\beta$-Carotene & Polyglycerol esters of fatty acids & $170-270$ & 35 \\
Soybean oil & & &
\end{tabular}

\footnotetext{
*Tween: Polysorbate

*WPC: Whey protein concentrate

*WPH: Whey protein hydrolysate

*SC: Sodium caseinate

** Medium chain triglyceride
} 
emulsions. In ultrasound emulsification, the energy input is provided by sonicator probe. The sonicator probe is placed in the target liquids, where the intense mechanical vibrations are generated, leading to cavitation effects. The collapse of the micro bubbles occurs by cavitation forces in the immediate vicinity of the sonicator probe that leads to droplet disruption. Ultrasound can be generated by mechanically and electrically. A schematic diagram of an ultrasonic emulsification is shown in Fig. 7. In general, 1-30 $\mu \mathrm{m}$ order of emulsions can be produced by ultrasonic emulsification. Recently, it has been reported that nano-order of emulsions can also be produced by ultrasonic emulsification (Table 4) [36-39]. The droplet diameter of produced emulsion depends on the ultrasonic parameters such as irradiation intensity, irradiation time, emulsifier type and concentration, among others [36].

\subsection{Membrane emulsification}

Membrane emulsification (ME) was proposed by Nakashima et al. [40]. In membrane emulsification process, the microporous membranes were used for produce droplets by pressing the dispersed phase through the pores of microporous membrane directly into the continuous phase (Fig. 8) [40]. Compared to conventional emulsification, the advantages of ME can be carried out with lower energy input to generate smaller sized droplets and narrow droplet size distributions. The droplet diameter depended on the pore size of porous membranes, and the coefficient of variation on size of the droplets produced was about $10 \%$. The different types of ME system and emulsified case are shown in Table 5 [41-46]. Membrane emulsification is applicable to $\mathrm{O} / \mathrm{W}$ emulsions, W/O emulsions and multiple emulsions. Shirasu porous glass (SPG) is a commonly used membrane for emulsion preparation. In general, the droplet diameters were determined to be $3-10$ times bigger than the mean diameter of the membranes pores. On the other hand, premix emulsification can also be used to produce emulsions with high dispersed phase fraction. In this case, the droplet diameters may be 1-2 times larger than the mean diameter of the membranes pores.

\subsection{Emulsification via micro/nano engineered devices}

Microfluidic devices available for flowing fluids on a

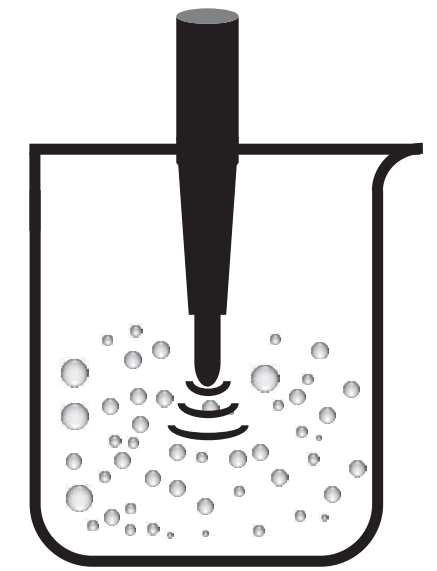

Fig. 7 Schematic representation of ultrasonic homogenizer.

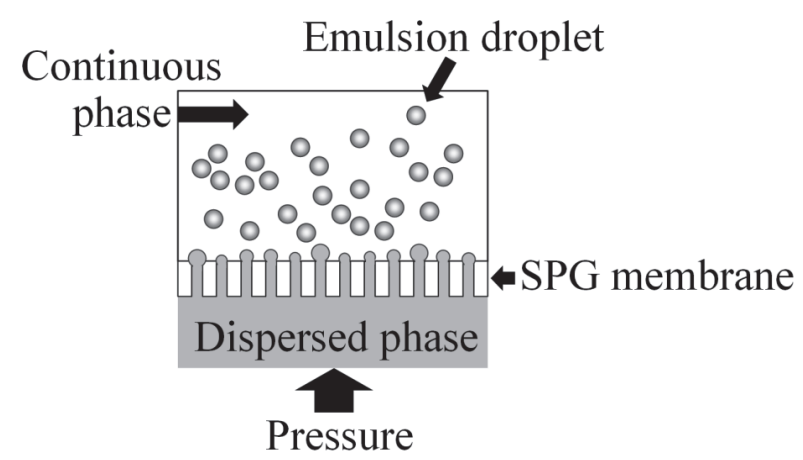

Fig. 8 Schematic representation of membrane emulsification using Shirasu porous glass (SPG) membrane.

Table 4 An overview of reference on $\mathrm{O} / \mathrm{W}$ nano-emulsion formulation using ultrasonic homogenizer.

\begin{tabular}{|c|c|c|c|}
\hline Dispersed Phase & Emulsifier* & Droplet Diameter (nm) & Reference \\
\hline $\begin{array}{l}\text { Sunflower oil/ } \\
\text { Canola oil }\end{array}$ & Tween 80 & 40 & 36 \\
\hline Linseed oil & Tween 40 & 150 & 37 \\
\hline $\begin{array}{l}\text { Olive oil/ } \\
\text { Sesame oil/ } \\
\text { Soybean oil }\end{array}$ & Pluronic ${ }^{\circledR} \mathrm{F}-68$ & $<500$ & 38 \\
\hline Soybean oil & $\begin{array}{l}\text { Phosphatidylcholine, } \\
\text { Sodium palmitate, } \\
\text { Sucrose palmitate }\end{array}$ & 58 & 39 \\
\hline
\end{tabular}

*Tween: Polysorbate 
Table 5 Different type of membrane emulsification systems and applications.

\begin{tabular}{|c|c|c|c|c|c|}
\hline Membrane type and material & Process Design & Dispersed Phase & Emulsifier* & $\begin{array}{c}\text { Droplet } \\
\text { Diameter }(\mu \mathrm{m})\end{array}$ & Reference \\
\hline Tube membrane (SPG, Ceramic) & Cross flow & Sunflower oil & $\begin{array}{l}\text { Tween 20, 80, } \\
\text { Lecithin, WPI }\end{array}$ & $2.6-6.5$ & 41 \\
\hline $\begin{array}{l}\text { Tube membrane } \\
\text { (Micro-porous glass) }\end{array}$ & Stirred cell & Sunflower oil & Tween 20 & $40-400$ & 42 \\
\hline $\begin{array}{l}\text { Flat membrane } \\
\text { (Micro-porous glass) }\end{array}$ & Stirred cell & $\begin{array}{l}\text { Pumpkinseed oil / } \\
\text { Sunflower oil }\end{array}$ & $\begin{array}{l}\text { Tween20, Pluronic } \\
\text { F-68 }\end{array}$ & $74-273$ & 43 \\
\hline Flat membrane (Stainless steel) & Rotatingflat & Paraffin & Tween 20 & $79-259$ & 44 \\
\hline Tube membrane (Stainless steel) & Vibrating and rotating & Sunflower oil & Tween 20 & $30-50$ & 45 \\
\hline $\begin{array}{l}\text { Flat membrane } \\
\text { (SPG, Polyether sulfone) }\end{array}$ & Premix & Corn oil & Tween 20,80 & $1-12$ & 46 \\
\hline
\end{tabular}

*Tween: Polysorbate

*WPI: Whey protein isolate

chip is an emerging and multidiscipline technology. It was developed in the early 1990's. Emulsification techniques via microchannel (MC) devices have been proposed for producing mono-disperse emulsions in the last two decades [47]. Emulsification via micro devices is summarized in Table 6 [48-53, 55]. We presented below a brief introduction about each devices:

$\mathrm{T}$ - and Y-junctions are frequently used microfluidic geometries to produce mono-dispersed droplets by using the cross-flow shear method. The cross-flow shear method utilizes shear force, imposed by an immiscible cross-flow fluid to generate droplets (Fig. 9a and 9b) $[48,49]$. The flow-focusing geometry implemented in a microfluidic device is shown in Fig. 9c. A liquid flows into the central channel and a second immiscible liquid flows into the two outer channels. The two liquid phases are then forced to flow through a small orifice that is located downstream of the three channels. The outer fluid exerts pressure and viscous stresses that force the inner fluid into a narrow thread, which then breaks inside or downstream of the orifice. Figure $9 \mathrm{~d}$ shows a glass capillary device consisting of two round glass capillaries lying end-to-end within a square glass tube. When the two fluids enter the collection tube, emulsion droplets are generated without chemical surface modification, in which the droplets obtained are smaller than the size of the collection tube. Multiple emulsion can also be prepared by this device [51].

Microchannel (MC) emulsification is also a technique for producing monodispersed emulsions in which droplets are formed by spontaneous transformation caused by interfacial tension. It can be divided into grooved-type MC plate and straight-through [52-53]. Grooved-type MC plate is shown in Fig. 9e, parallel grooves fabricated on a terrace are arranged on four sides of the plate. The dispersed phase supplied through a central hole is forced to flow through MCs, because the plate is sealed with a transparent cover plate. The dispersed phase takes a disk-like shape on terrace and this shape is characterized by a higher interfacial area per unit volume than a spherical shape, resulting in hydrodynamic instability. This instability is a driving force for spontaneous transformation of dispersed phase into spherical droplets. Asymmetric straight-through MCs is shown in Fig. 9f. It has circular channels on the upstream (bottom) side and slots on the downstream (top) side. Asymmetric plate is useful for low viscosity oils (less than $1 \mathrm{mPa}$ ). The mean droplet diameter of emulsion produced by asymmetric plate can be controlled by shape and size of MC. A $30 \mu \mathrm{m}$-order of polyunsaturated fatty acids (PUFA)-

Table 6 Summary of emulsification via micro devices.

\begin{tabular}{|c|c|c|c|c|c|c|}
\hline & Device type & Monodispersity & $\begin{array}{c}\text { Droplet } \\
\text { Diameter }(\mu \mathrm{m})\end{array}$ & $\begin{array}{l}\text { Productivity } \\
(\mathrm{mL} / \mathrm{h})\end{array}$ & Fabrication & Reference \\
\hline \multirow{3}{*}{$\begin{array}{l}\text { Micro fluidics } \\
\text { emulsification }\end{array}$} & $\mathrm{T} / \mathrm{Y}$ junction & Good & $50-500$ & $1-300$ & Simple & 48,49 \\
\hline & Flow focusing & Good & -100 & $1-50$ & Elaborate & 50 \\
\hline & Micro capillary & Good & -10 & $1-10$ & Elaborate & 51 \\
\hline \multirow{3}{*}{$\begin{array}{l}\text { Microchannel } \\
\text { emulsification }\end{array}$} & Grooved microchannel & Excellent & $1-500$ & $1-10$ & Simple & 52 \\
\hline & $\begin{array}{l}\text { Asymmetric straight through } \\
\text { microchannel }\end{array}$ & Good & $5-2000$ & $1-1000$ & Elaborate & 53 \\
\hline & Edge-based droplet generation & Good & $5-10$ & $1-10$ & Simple & 54 \\
\hline
\end{tabular}


(a)

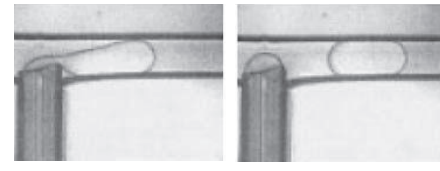

(b)

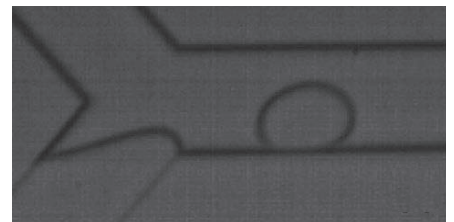

(c)

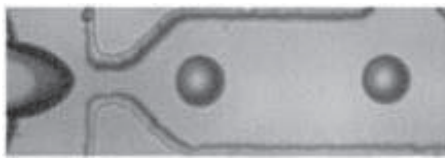

(d)

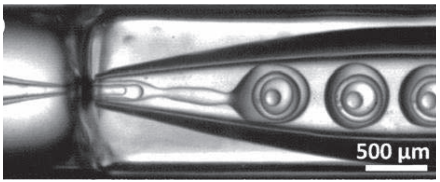

(e)

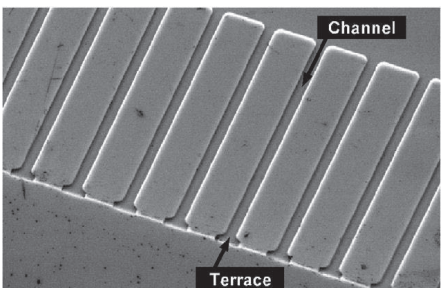

(f)

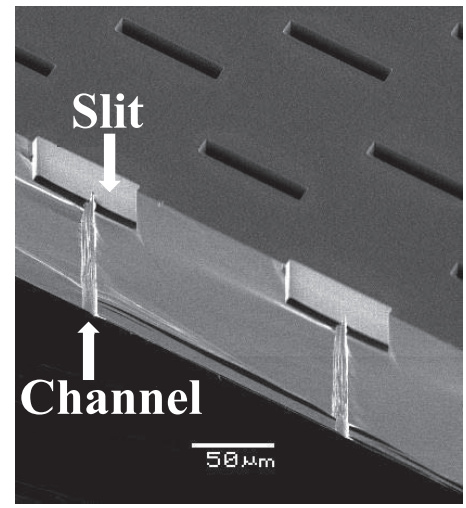

(g)

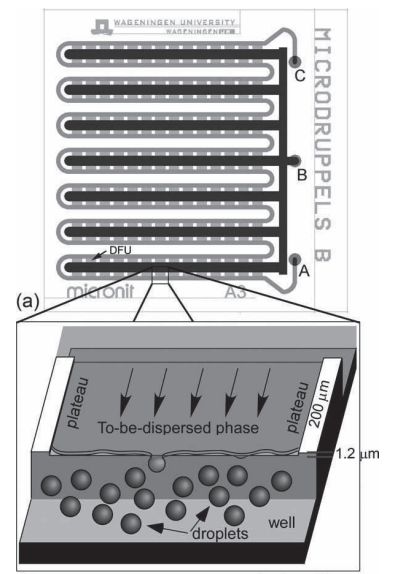

(a) T junction, (b) Y junction, (c) flow focusing, (d) micro capillary, (e) groove microchannel, (f) asymmetric straight through microchannel, (g) edge-based droplet generation

Fig. 9 Different type of micro devices which can produce monodispersed droplets [48-53, 57].

loaded $\mathrm{O} / \mathrm{W}$ emulsions and high concentration of vitamin $\mathrm{C}$-loaded multiple emulsions have been produced by asymmetric straight-through MCs [54, 55]. Recently nano-channel has also been developed, and monodispersed emulsions with the mean droplet diameter of approximately $500 \mathrm{~nm}$ have been produced [56].

Edge-based droplet generation (EDGE) emulsification was proposed by van Dijke et al. [57], where simultaneous formation of many oil droplets in a single EDGE module occurs. In EDGE module, multiple droplets are formed at the edge of a shallow but rather wide rectangular plateau (Fig. 9g).

\subsection{Phase inversion emulsification}

Some methods have been developed to produce nanoemulsions by inducing a phase inversion in emulsions from a $\mathrm{W} / \mathrm{O}$ emulsion to $\mathrm{O} / \mathrm{W}$ emulsion or vice versa, such as phase inversion temperature (PIT), phase inversion composition (PIC), and emulsion inversion point (EIP) methods [58-60]. All these methods depend on the changing of the spontaneous curvature of the surfactant. For non-ionic surfactants, the hydrophilic-lipophilic bal- ance (HLB) can be changed with temperature. An O/W emulsion formed at low temperature, and a W/O emulsion at higher temperature. During cooling, the system crosses a point of zero spontaneous curvature and minimal surface tension, promoting the formation of finely dispersed oil droplets. This method is called PIT method (Fig. 10). It was reported that an emulsion with droplet diameter around $100 \mathrm{~nm}$ can be produced using this method [61]. Here, the stability of resulting emulsions was greater and depended on the storage temperature. Therefore, the rapid cooling is required after producing the emulsion [62]. On the other hand, a PIC method starts from W/O emulsion, which is an equilibrium phase of oil, water, and surfactant, in which the surfactant is already at the water/oil interfaces with a curvature turned toward water. Then a large addition of water, which causes an inversion of the spontaneous curvature of the emulsifier, now turned toward the oil. After that, an emulsion with diameters of around $100 \mathrm{~nm}$ can be obtained (Fig. 11). Both PIT and PIC methods are reversible. In contrast, in case of EIP method, the change from $\mathrm{W} / \mathrm{O}$ emulsion to $\mathrm{O} / \mathrm{W}$ emulsion or vice-versa is 


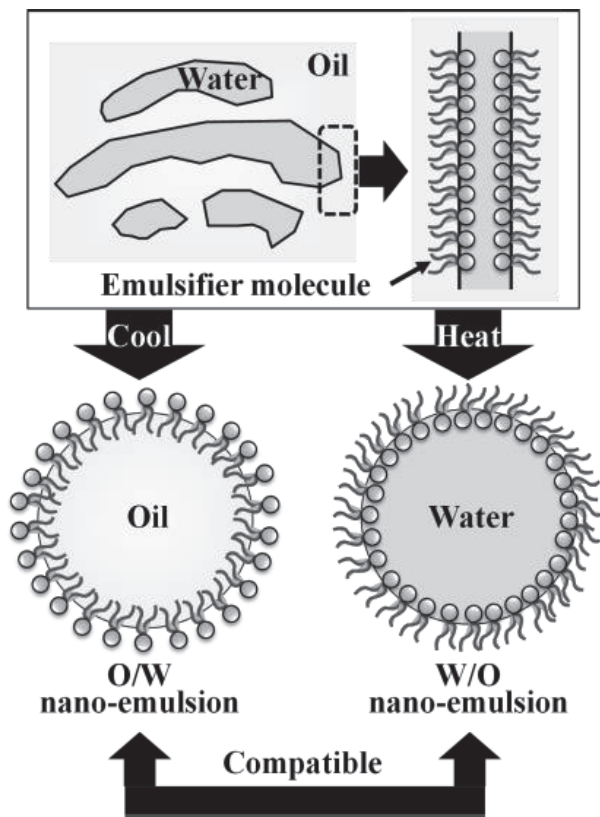

Fig. 10 Schematic representation of phase inversion temperature (PIT)

through a catastrophic phase inversion. In this case, a $\mathrm{W} / \mathrm{O}$ emulsion with a high oil to water ratio is formed using a low molecular weight emulsifier, and then increasing amounts of water are added to the system with continuous stirring (Fig. 12). Above a critical water content, the water droplet concentration is higher that the emulsion reaches a phase inversion point where it will change from $\mathrm{W} / \mathrm{O}$ emulsion to $\mathrm{O} / \mathrm{W}$ emulsion. The droplet diameter produced by EIP method depends on process variables (stirring speed, rate of water addition). It has been reported that an emulsion with droplet diameter around $100 \mathrm{~nm}$ can be produced by EIP method [63].

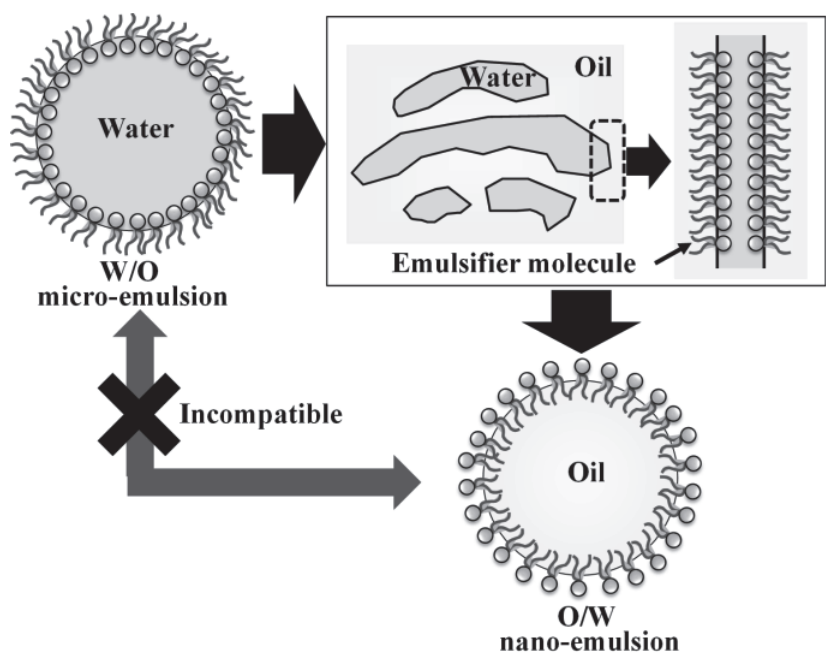

Fig. 12 Schematic representation of emulsion inversion point (EIP)

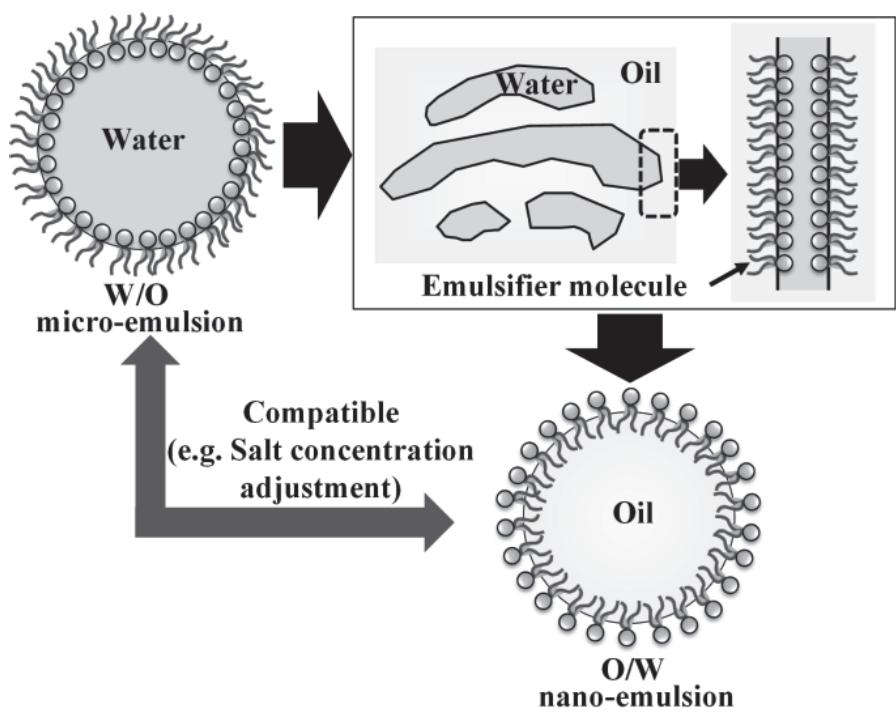

Fig. 11 Schematic representation of phase inversion composition (PIC).

\subsection{Solvent displacement/emulsification evaporation}

Figure 13 shows the schematic representation of solvent displacement method. Initially the functional compounds are dissolved in an organic solvent e.g., alcohol or acetone as an oil phase, while the oil phase is added to the aqueous phase drop-by-drop under magnetic stirring leads to a dispersion. After this step, some water is added to the dispersions, in order to allow the diffusion of the organic solvent into the water. Additional evaporation process is used to remove the organic solvent from the dispersions. Emulsification evaporation is also one of the most common methods used for preparing nano-dispersions. With this method, the functional compounds

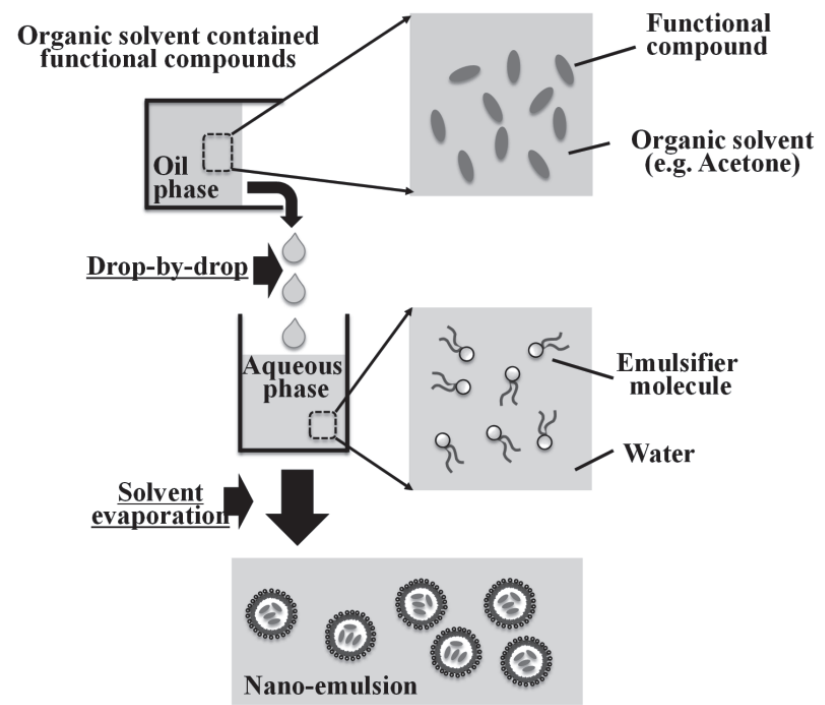

Fig. 13 Schematic representation of solvent displacement method. 
are dissolved in a lipophilic solvent e.g., hexane as an oil phase, and an $\mathrm{O} / \mathrm{W}$ emulsion is formed by conventional emulsification with the aqueous phase containing an emulsifier. Converting the emulsion into nano-dispersion is then carried out by evaporating the solvent, and the particle size decreases to the nano-size range (Fig. 14). Table 7 summarizes some references where solvent displacement/emulsification evaporation methods were used [64-67]. The particles produced using these methods may have from several $10 \mathrm{~nm}$ to $200 \mathrm{~nm}$-order.

\subsection{Spontaneous emulsification}

Spontaneous emulsification is also one of methods which can prepare nano-sized emulsion. An emulsion is spontaneously formed when two liquids such as organic phase and aqueous phase are mixed together at a special temperature. Spontaneous emulsification was depended on the chemical composition of phases and the presence of surfactants. Figure 15 shows the schematic represen-

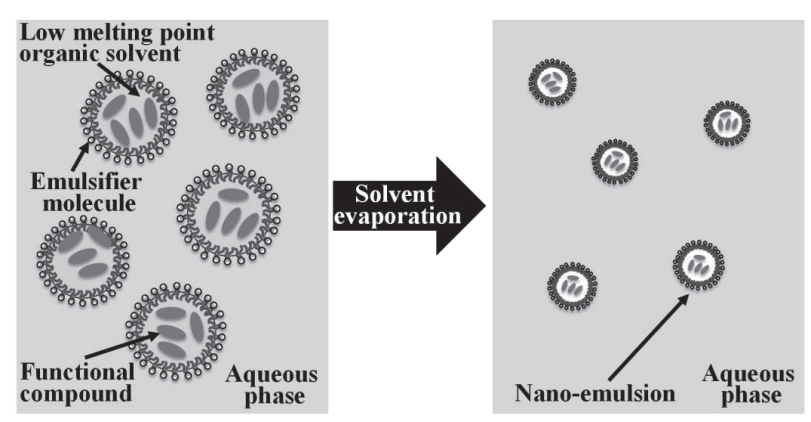

Fig. 14 Schematic representation of solvent evaporation method. tation of spontaneous emulsification [68-69]. Initially, the organic and aqueous phases are mixed together. After mixing, the water-miscible solvent and surfactant move from the organic phase into the aqueous phase, which creates a large turbulent force at the oil water interface. Some references using spontaneous emulsification are summarized in Table 8 [70-72].
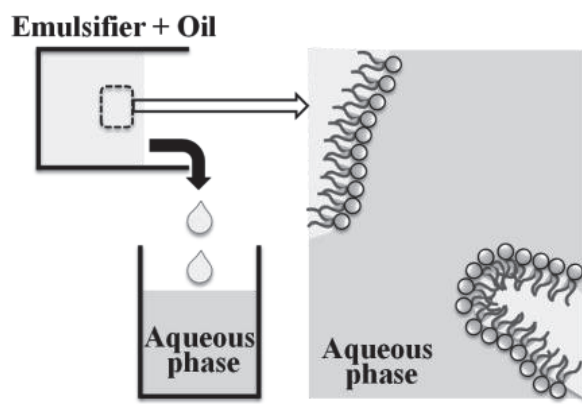

After mixing
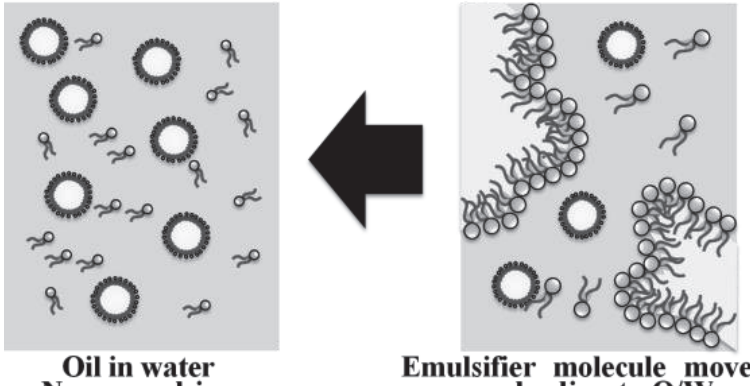

Emulsifier molecule move to aqueous leading to $\mathrm{O} / \mathrm{W}$ nanoemulsion formulations.

Fig. 15 Schematic representation of spontaneous emulsification.

Table 7 An overview of literature researches on oil in water nano-emulsion formation using solvent displacement and evaporation methods.

\begin{tabular}{lllcc}
\hline \multicolumn{1}{c}{ Dispersed Phase } & \multicolumn{1}{c}{$\begin{array}{c}\text { Functional } \\
\text { Compounds }\end{array}$} & \multicolumn{1}{c}{ Emulsifier* } & $\begin{array}{c}\text { Droplet Diameter } \\
(\mathrm{nm})\end{array}$ & Reference \\
\hline Hexane & $\beta$-Carotene & Polyglycerol esters of fatty acids & $60-140$ & 64 \\
Hexane & $\beta$-Carotene & Casein sodium & 18 & 65 \\
Corn oil/Ethyl acetate & - & Whey protein & $<70$ & 66 \\
Acetone & $\beta$-Carotene & Tween 20 & 77 & 67 \\
\hline
\end{tabular}

*Tween: Polysorbate

Table 8 An overview of literature researches on oil in water nano-emulsion formation using spontaneous emulsification method.

\begin{tabular}{|c|c|c|c|c|}
\hline Dispersed Phase & Functional Compounds & Emulsifier* & $\begin{array}{l}\text { Droplet Diameter } \\
(\mathrm{nm})\end{array}$ & Reference \\
\hline $\mathrm{MCT}^{* *}$ & $\alpha$-Tocopherol & Span 80,85 , Tween 20,80 & $100-600$ & 70 \\
\hline $\mathrm{MCT}^{* *}$ & Oligothymidylate & Lecithin & 225 & 71 \\
\hline Palm oil & Vitamin E & Pluronic ${ }^{\circledR} \mathrm{F}-68$ & 94 & 72 \\
\hline
\end{tabular}

*Span: Sorbitan monooleate

*Tween: Polysorbate

** Medium chain triglyceride 


\section{Characterization of micro/nano-emulsions}

Emulsion are thermodynamically unstable systems that tend to breakdown over time through different physicochemical mechanisms [1]. Here, we will mainly focus on the physical stability (Fig. 16). The physical stability of emulsion can be evaluated by Stokes' law equation:

$$
V_{\text {stokes }}=\frac{2 r^{2}\left(\rho_{0}-\rho\right) g}{9 \eta_{0}}
$$

where, $V_{\text {stokes }}$ is creaming velocity, $r$ is the droplet radius, $\rho$ is droplet density, $\rho_{0}$ is the density of continuous phase, $\eta_{0}$ is the viscosity of continuous phase, and $g$ is the gravitational acceleration. In here, the $V_{\text {stokes }}$ value is negative for creaming, and positive for settling. This equation shows that the creaming can be affected by droplet radius, viscosity of continuous phase and density difference between the oil and water phases. On the other hand, the stability of an emulsion can also be evaluated by measuring the change in droplet diameter when the emulsion is stored for a specified length of time, or exposed to some environmental stresses, such as heating, freezing and stirring. The parameter named emulsion stability index (ESI) based on droplet diameter measurements, is given below:

$$
\mathrm{ESI}=\frac{d_{0} \times t}{d_{t}-d_{0}}
$$

where, $d_{0}$ is the initial mean droplet diameter of the emulsion and $d_{t}$ is the mean droplet diameter measured at time $t$ [1]. It should be mentioned that there are many

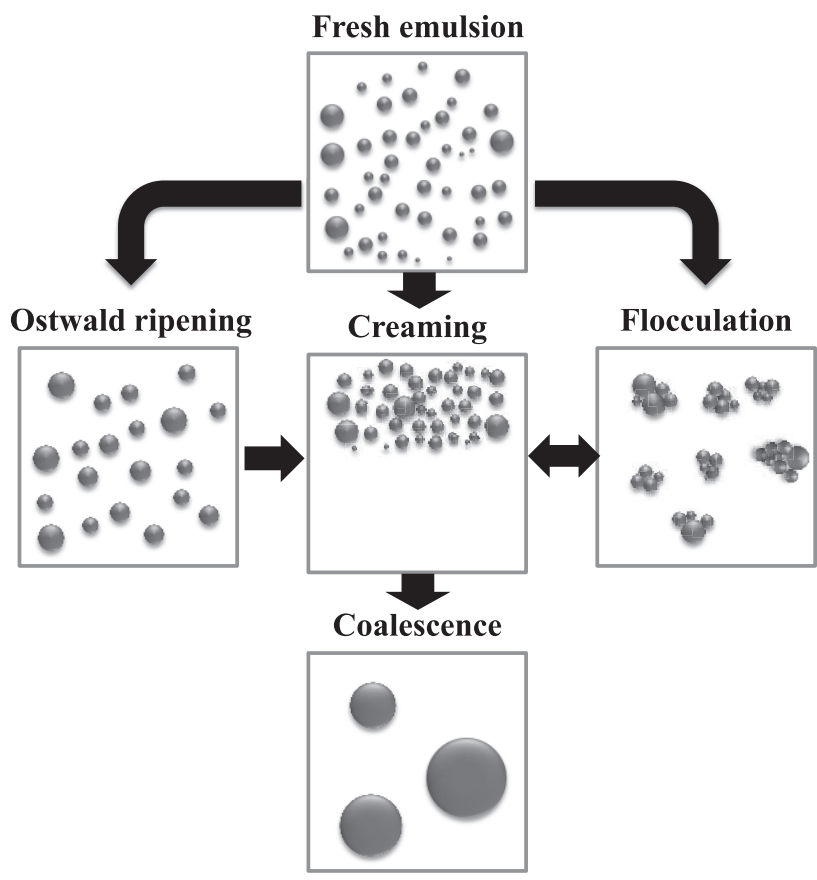

Fig. 16 Schematic representation of emulsion destabilization. potential problems associated with any methods used to define the ESI for comparing the effectiveness of different types of emulsifiers. Increases on droplet diameter in an emulsion may be caused by different mechanisms, such as flocculation, coalescence, or Ostwald ripening. It is important to establish which mechanism is dominant in a particular system. The mean droplet diameter does not usually increase linearly with the time, so that the value of ESI may depend on the time during the measurements. It is therefore important to use a standardized storage time to compare the emulsifier effectiveness, for instance, 1 day or 1 week. The particle size distribution may also shift from a single peak to multi-peaks with the storage time. In some cases, the changes in particle size distribution with time are more important than the mean droplet diameter. In addition, the ESI strongly depends on the type of mean droplet diameter. At present, there is no single parameter, such as ESI, which can be used to quantitatively compare the effectiveness of emulsifiers. Therefore, the effectiveness of emulsifier on stabilizing droplets against aggregation is usually evaluated by the mean droplet diameters or droplet size distributions, rather than by a calculated ESI. However, the ESI is more effective compared to a series of emulsifiers under the same conditions.

For micro/nano-emulsion containing functional compounds, both the emulsion stability and functional compounds stability have to be evaluated. Spectrophotometer and HPLC are the main equipment used to evaluate these parameters. Moreover, the bioavailability and toxicity of emulsion containing functional compounds also have to be evaluated by in vitro gastrointestinal model, animal testing or in some cases, by human test.

\section{Application of micro/nano-emulsions in food}

Micro/nano-emulsions can be used in many fields. There is increasing interest in food industry in utilizing them as delivery carriers containing lipophilic functional food compounds (e.g., vitamin $\mathrm{A}, \mathrm{D}_{3}, \mathrm{E}$, polyphenols, carotenoids, phytosterols, and flavor compounds) to protect and deliver those compounds, asides from increasing the bioavailability of those lipophilic compounds. For instance, citral is one of the most important flavor compound that is widely used in the food and beverage industries. Citral is chemically unstable and degrades over time in an acidic environment; also can be affected by heat, light and oxygen [73]. It has been reported that the stability of citral can be improved by emulsification 
Table 9 Commercial nano-emulsion formulations.

\begin{tabular}{|c|c|c|}
\hline Commercial Name & Manufacturer & Reference \\
\hline Canola Active Oil & Shemen Industries, Israel & $\begin{array}{l}\text { http://www.nanotechproject.org/cpi/products/canola- } \\
\text { active-oil/ (20140908) }\end{array}$ \\
\hline NanoResveratrol ${ }^{\mathrm{TM}}$ & Life Enhancement, USA & $\begin{array}{l}\text { http://jp.iherb.com/life-enhancement-nanoresveratrol- } \\
\text { 1-7-fl-oz-50-ml/8975 (20140908) }\end{array}$ \\
\hline $\begin{array}{l}\text { Nutri-Nano }{ }^{\mathrm{TM}} \mathrm{CoQ}- \\
103.1 x \text { Softgels }\end{array}$ & Solgar, USA & $\begin{array}{l}\text { http://simplysolgar.co.uk/collections/coenzyme-q-10 } \\
\text { (20140908) }\end{array}$ \\
\hline $\begin{array}{l}\text { Spray for Life } \\
\text { Vitamin Supplements }\end{array}$ & $\begin{array}{l}\text { Health Plus International }{ }^{\circledR} \text {, } \\
\text { Inc., USA }\end{array}$ & $\begin{array}{l}\text { http://www.nanotechproject.org/cpi/products/spray-for- } \\
\text { life-r-vitamin-supplements/ (20140908) }\end{array}$ \\
\hline $\begin{array}{l}\text { Spray for Life } \\
\text { Vitamin Supplements }\end{array}$ & $\begin{array}{l}\text { Health Plus International }{ }^{\circledR} \text {, } \\
\text { Inc., USA }\end{array}$ & $\begin{array}{l}\text { http://www.nanotechproject.o rg/cpi/products/spray- } \\
\text { for-life-r-vitamin-supplements/ (20140908) }\end{array}$ \\
\hline Omega 3 Bread & Tip-Top Bakery, Australia & $\begin{array}{l}\text { http://www.tiptop.com.au/healthnutrition/nutrition-fact- } \\
\text { sheets/omega-3 (20140908) }\end{array}$ \\
\hline Color particles & Fujifilm Co., Japan & http://astalift-white.jp/technology_nano.html (20140908) \\
\hline
\end{tabular}

method $[74,75]$. Phytosterol can reduce cholesterol levels in humans. Due to the water insolubility, incorporation of phytosterol into foods is difficult. Recently, some research groups produced emulsions containing high concentrations of phytosterol [76-78]. In addition to this, the encapsulation of lycopene [79], astaxanthin [80], coenzyme Q10 [81] also has been reported by different research groups. Some reports using nano-emulsions are also summarized in Table 9.

\section{Conclusions}

This article reviews on the current status of micro/ nano-emulsion containing functional food components preparation and characterization, and presents some applications of micro/nano-emulsions into food industry.

Recently, different types of devices and methods have been developed to produce micro/nano-emulsions. We mentioned some of them in this paper. Micro/nanoemulsion based materials have a large surface area-tovolume ratio. In the future further applications, such as the development of new emulsification systems, as well as functional foods delivery systems or drug delivery systems, are expected.

\section{References}

1) D. J. McClements; "Food Emulsions" 2nd ed., CRC, 2004, pp. 3-26.

2) D. J. McClements; Emulsion design to improve the delivery of functional lipophilic components. Annu. Rev. Food Sci. Technol., 1, 241-269 (2010).

3) P. Izquierdo, J. Esquena, T. F. Tadros, J. C. Dederen, J. Feng, M. J. Garcia-Celma, N. Azemar, C. Solans; Phase behavior and nano-emulsion formation by the phase inversion temperature method. Langmuir, 20, 6594-6598 (2004).

4) A. Abraham; "Multiple Emulsions Technology and Applications”, John Wiley \& Sons, Inc., 2007, pp. 1-28.

5) X. Li, N. Anton, G. Zuber, M. Zhao, N. Messaddeq, F. hallouaed, H. Fessi, T. F. Vandamme; Iodinated $\alpha$-tocopherol nano-emulsions as non-toxic contrast agents for preclinical X-ray imaging. Biomaterials, 34, 481-491 (2013).

6) A. Trentin, S. De Lamo, C. Güell, F. López, M. Ferrando; Protein-stabilized emulsions containing beta-carotene produced by premix membrane emulsification. J. Food Eng., 106, 267-274 (2011).

7) K. Ahmed, Y. Li, D. J. McClements, H, Xiao; Nanoemulsionand emulsion-based delivery systems for curcumin Encapsulation and release properties. Food Chem., 132, 799-807 (2012).

8) F. Liu, C. H. Tang; Phytosterol colloidal particles as pickering stabilizers for emulsions J. Agric. Food Chem., 62, 51335141 (2014).

9) R. Bou, C. Boon, A. Kweku, D. Hidalgo, E. A. Decker; Effect of different antioxidants on lycopene degradation in oil-inwater emulsions. Eur. J. Lipid Sci. Technol., 113, 724-729 (2011).

10) Y. S. Rhee, C. W. Park, T. Oh, J. Y. Kim, J. M. Ha, B. J. Lee, K. H. Lee, S. C. Chi, E. S. Park; Effect of electrokinetic stabilizers on the physicochemical properties of propofol emulsions. Int. J. Pharm., 398, 21-27 (2010).

11) P. Deveda, A. Jain, N. Vyas, H. Khambete, S. Jain; Gellified emulsion for sustain delivery of itraconazole for topical fungal diseases. Int. J. Pharm. Pharm. Sci., 2, 104-112 (2010).

12) C. R. Kokare, S. A. kumbhar, A. Patil. Indian J. Pharm. Edu. Res., 47, 172-177 (2013).

13) Y. Zhu, Q. Z. Long, B. Zhou, P. D. Prezler, H. Y. Zhong; Antioxidant activity of phenolic compounds in bulk camellia 
oil and corresponding oil in water $(\mathrm{O} / \mathrm{W})$ emulsions. Adv. J. Food Sci. Technol., 5, 1238-1243 (2013).

14) T. Beppu, K. Sugimoto, K. Shiraki, M. Tameda, K. Takeda; Clinical utility of transarterial infusion chemotherapy using cisplatin-lipiodol emulsion for unresectable hepatocellular carcinoma. Anticancer Res., 32, 4923-4930 (2012).

15) F. A. Araújo, R. G. Kelmann, B. V. Araújo, R. B. Finatto, H. F. Teixeira, L. S. Koester; Development and characterization of parenteral nanoemulsions containing thalidomide. Eur. J. Pharm. Sci., 42, 238-245 (2011).

16) M. A. Neves, H. S. Ribeiro, K. B. Fujiu, I. Kobayashi, M. Nakajima; Formulation of controlled size PUFA-loaded oilin-water emulsions by microchannel emulsification using beta-carotene-rich palm oil. Ind. Eng. Chem. Res., 47, 64056411 (2008).

17) S. Souilem, I. Kobayashi, M. A. Neves, L. Jlaiel, H. Isoda, S. Sayadi, M. Nakajima; Interfacial characteristics and microchannel emulsification of oleuropein-containing triglyceride oil-water systems. Food Res. Int., 62, 467-475 (2014).

18) P. Yamada, M. Zarrouk, K. Kawasaki, H. Isoda; Inhibitory effect of various Tunisian olive oils on chemical mediator release and cytokine production by basophilic cells. J. Ethnopharmacol., 116, 279-287 (2008).

19) H. Isoda, H. Motojima, D. Margout, M. Neves, J. Han, M. Nakajima, M. Larroque; Antiallergic effect of picholine olive oil-in-water emulsions through $\beta$-hexosaminidase release inhibition and characterization of their physicochemical properties. J. Agric. Food Chem., 60, 7851-7858 (2012).

20) S. M. Jafari, Y. He, B. Bhandari; Production of sub-micron emulsions by ultrasound and microfluidization techniques. J. Food Eng., 82, 478-488 (2007).

21) K. R. Kuhn, R. L. Cunha; Flaxseed oil-whey protein isolate emulsion: effect of high pressure homogenization. J. Food Eng., 111, 449-457 (2012).

22) H. Bouaouina, A. Desrumaux, C. Loisel, J. Legrand; Functional properties of whey proteins as affected by dynamic high-pressure treatment. Int. Dairy J., 16, 275-284 (2006).

23) J. Floury, A. Desrumaux, M. A. V. Axelos, J. Legrand; Effect of high pressure homogenisation on methylcellulose as food emulsifier. J. Food. Eng., 58, 227- 238 (2003).

24) Y. Yuan, Y. X. Gao, J. Zhao, L. K. Mao; Characterization and stability evaluation of $\beta$-carotene nanoemulsions prepared by high pressure homogenization under various emulsifying conditions. Food Res. Int., 41, 61-68 (2008).

25) T. Tadros, R. Izquierdo, J. Esquena, C. Solans; Formation and stability of nano-emulsions. Adv. Colloid Interface Sci., 108109, 303-318 (2004).

26) L. K. Mao, D. X. Xu, J. Yang, F. Yuan, Y. X. Gao, J. Zhao; Effects of small and large molecule emulsifiers on the char- acteristics of beta-carotene nanoemulsions prepared by high pressure homogenization. Food Tech. Biotechnol., 47, 336342 (2009).

27) X. Y. Wang, Y. Jiang, Y. W. Wang, M. T. Huang, C. T. Ho, Q. R. Huang; Enhancing anti-inflammation activity of curcumin through $\mathrm{O} / \mathrm{W}$ nanoemulsions. Food Chem., 108, 419-424 (2008).

28) M. Wulff-Perez, M.J. Galvez-Ruiz, J. de Vicente, A. MartinRodriguez; Delaying lipid digestion through steric surfactant pluronic F68: a novel in vitro approach. Food Res. Int., 43, 1629-1633 (2010).

29) S. M. Jafari, Y. He, B. Bhandari; Optimization of nanoemulsions production by microfluidization. Eur. Food Res. Technol., 225, 733-741 (2007).

30) T. J. Wooster, M. Golding, P. Sanguansri; Impact of oil type on nanoemulsion formation and Ostwald ripening stability. Langmuir, 24, 12758-12765 (2008).

31) J. Hatanaka, Y. Kimura, L. F. Zhong, S. Onoue, S. Yamada; Physicochemical and pharmacokinetic characterization of water-soluble Coenzyme Q(10) formulations. Int. J. Pharm., 363, 112-117 (2008).

32) J. Hatanaka, H. Chikamori, H. Sato, S. Uchida, K. Debari, S. Onoue, S. Yamada; Physicochemical and pharmacological characterization of alpha-tocopherol-loaded nano-emulsion system. Int. J. Pharm., 396, 188-193 (2010).

33) C. Qian, D. J. McClements; Formation of nanoemulsions stabilized by model food-grade emulsifiers using high-pressure homogenization: Factors affecting particle size. Food Hydrocoll., 25, 1000-1008 (2011).

34) Z. Wang, M. A. Neves, L. J. Yin, I. Kobayashi, K. Uemura, M. Nakajima; In vitro gastrointestinal digestability of soybean oil-in-water emulsion droplets stabilized by polyglycerol eaters of fatty acid. Food Sci. Technol. Res., 18, 149-156 (2012).

35) L. J. Yin, I. Kobayashi, M. Nakajima; Effect of polyglycerol esters of fatty acids on the physicochemical properties and stability of $\beta$-carotene emulsions during digestion in simulated gastric fluid. Food Biophys., 3, 213-218 (2008).

36) T. S. H. Leong, T. J. Wooster, S. E. Kentish, M. Ashokkumar; Minimising oil droplet size using ultrasonic emulsification. Ultrason. Sonochem., 16, 721-727 (2009).

37) S. Kentish, T. Wooster, M. Ashokkumar, S. Balachandran, R. Mawson, L. Simons; The use of ultrasonics for nanoemulsion preparation. Innov. Food Sci. Emerg. Technol., 9, 170-175 (2008).

38) M. Wulff-Perez, A. Torcello-Gomez, M.J. Galvez-Ruiz, A. Martin-Rodriguez; Stability of emulsions for parenteral feeding: preparation and characterization of $\mathrm{o} / \mathrm{w}$ nanoemulsions with natural oils and pluronic $f 68$ as surfactant. Food Hydrocol., 23, 1096-1102 (2009). 
39) S. Takegami, K. Kitamura, H. Kawada, Y. Matsumoto, T. Kitade, H. Ishida, C. Nagata; Preparation and characterization of a new lipid nano-emulsion containing two cosurfactants, sodium palmitate for droplet size reduction and sucrose palmitate for stability enhancement. Chem. Pharm. Bull, 56, 1097-1102 (2008).

40) T. Nakashima, M. Shimizu; Preparation of $\mathrm{O} / \mathrm{W}$ emulsion by porous glass membrane. The 21st Autumn Meeting of the Soc. Chem. Eng., Japan. p. 86 (1988).

41) R. D. Hancocks, F. Spyropoulos, I. T. Norton; Comparisons between membranes for use in cross flow membrane emulsification. J. Food Eng., 116, 382-389 (2013).

42) S. R. Kosvintsev, G. Gasparini, R. G. Holdich, I. W. Cumming, M. T. Stillwell; Liquid-liquid membrane dispersion in a stirred cell with and without controlled shear. Ind. Eng. Chem. Res., 44, 9323-9330 (2005).

43) M. M. Dragosavac, M. N. Sovilj, S. R. Kosvintsev, R. G. Holdich, G. T. Vladisavljević; Controlled production of oilin-water emulsions containing unrefined pumpkin seed oil using stirred cell membrane emulsification. Membr. Sci., 322, 178-188 (2008).

44) G. T. Vladisavljević, R. A. Williams; Manufacture of large uniform droplets using rotating membrane emulsification. J. Colloid Interf. Sci., 299, 396-402 (2006).

45) R. G. Holdich, M. M. Dragosavac, G. T. Vladisavljević, S. R. Kosvintsev; Membrane emulsification with oscillating and stationary membranes. Ind. Eng. Chem. Res., 49, 3810-3817 (2010).

46) A. Nazir, K. Schroën, R. Boom; Premix emulsification: a review. J. Membr. Sci., 362, 1-11 (2010).

47) T. Tsukahara, K. Mawatari, T. Kitamori; Integrated extendednano chemical systems on a chip. Chem. Soc. Rev., 39, 10001013 (2010).

48) J. H. Xu, S. W. Li, J. Tan, G. S. Luo; Correlations of droplet formation in T-junction microfluidic devices: from squeezing to dripping. Microfluid. Nanofluid., 5, 711-717 (2008).

49) M. L. J. Steegmans, K. G. P. H. Schroën, R. M. Boom; Characterization of emulsification at flat microchannel y junctions. Langmuir, 25, 3396-3401 (2009).

50) C. A. Stan, S. K. Y. Tang, G. M. Whitesides; Independent control of drop size and velocity in microfluidic flow-focusing generators using variable temperature and flow rate. Anal. Chem., 81, 2399-2402 (2009).

51) S. H. Kim, D. A. Weitz; One-step emulsification of multiple concentric shells with capillary microfluidic devices. Angew. Chem. Int. Ed., 50, 8731-8734 (2011).

52) I. Kobayashi, K. Uemura, M. Nakajima; Formulation of monodisperse emulsions using submicron-channel arrays. Coll. Surf. A, 296, 285-289 (2007).
53) I. Kobayashi, T. Takano, R. Maeda, Y. Wada, K. Uemura, M. Nakajima; Straight-through microchannel devices for generating monodisperse emulsion droplets several microns in size. Microfluid. Nanofluid., 4,167-177 (2008).

54) M. A. Neves, H. S. Ribeiro, K. B. Fujiu, I. Kobayashi, M. Nakajima; Formulation of controlled size PUFA-loaded oilin-water emulsions by microchannel emulsification using $\beta$ -carotene-rich palm oil. Ind. Eng. Chem. Res., 47, 6405-6411 (2008).

55) N. Khalid, I. Kobayashi, M. A. Neves, K. Uemura, M. Nakajima, H. Nabetani; Monodisperse W/O/W emulsions encapsulating 1-ascorbic acid: insights on their formulation using microchannel emulsification and stability studies. Colloids Surf. A, 458, 69-77 (2014).

56) I. Kobayashi, M. Nakajima; Micro/nanochannel emulsification for generating monosize droplets. ASME 2012 Third International Conference on Micro/Nanoscale Heat and Mass Transfer (MNHMT) 2012-75238, pp. 103-108 (2012).

57) K. C. van Dijke, K. Schroën, A. van der Padt, R. M. Boom; EDGE emulsification for food-grade dispersions. J. Food Eng., 97, 348-354 (2010).

58) N. Anton, T. F. Vandamme; The universality of low-energy nano-emulsification. Int. J. Pharm., 377, 142-147 (2009).

59) M. M. Fryd, T. G. Mason; Advanced Nanoemulsions. Annu. Rev. Phys. Chem., 63, 493-518 (2012).

60) R. K. Thakur, C. Villette, J. M. Aubry, G. Delaplace; Dynamic emulsification and catastrophic phase inversion of lecithinbased emulsions. Colloids Surf. A, 315, 285-293 (2008).

61) J. J. Rao, D. J. McClements; Stabilization of phase inversion temperature nanoemulsions by surfactant displacement. J. Agric. Food Chem., 58, 7059-7066 (2010).

62) N. Anton, J. P. Benoit, P. Saulnier; Design and production of nanoparticles formulated from nano-emulsion templates a review. J. Control Release, 128, 185-199 (2008).

63) C. Bilbao-Sainz, R. J. Avena-Bustillos, D. F. Wood, T. G. Willams, T. H. McHugh; Nanoemulsions prepared by a lowenergy emulsification method applied to edible films. J. Agric. Food Chem., 58, 11932-11938 (2010).

64) C. P. Tan, M. Nakajima; Effect of polyglycerol esters of fatty acids on physicochemical properties and stability of $\beta$-carotene nanodispersions prepared by emulsification/evaporation method. J. Sci. Food Agric., 85, 121-126 (2005).

65) B. S. Chu, S. Ichikawa, S. Kanafusa, M. Nakajima; Preparation and characterization of beta-carotene nanodispersions prepared by solvent displacement technique. J. Agric. Food Chem., 55, 6754-6760 (2007).

66) S. J. Lee, D. J. McClements; Fabrication of protein-stabilized nanoemulsions using a combined homogenization and amphiphilic solvent dissolution/evaporation approach. Food 
Hydrocoll., 24, 560-569 (2010).

67) H. Ribeiro, B. S. Chu, S. Ichikawa, M. Nakajima; Preparation of nanodispersions containing beta-carotene by solvent displacement method. Food Hydrocoll., 22, 12-17 (2008).

68) M. Grzelczak, J. Vermant, E. M. Furst, L. M. Liz-Marzán Directed self-assembly of nanoparticles. ACS Nano, 4, 35913605 (2010).

69) G. M. Whitesides, B. Grzybowski; Self-assembly at all scales. Sci., 295, 2418-2421 (2002).

70) K. Bouchemal, S. Briancon, E. Perrier, H. Fessi; Nanoemulsion formulation using spontaneous emulsification: solvent, oil and surfactant optimisation. Int. J. Pharm., 280, 241251 (2004).

71) E. Martini, E. Fattal, E. M. de Oliveira, H. Teixeira; Effect of cationic lipid composition on properties of oligonucleotide/ emulsion complexes: Physico-chemical and release studies. Int. J. Pharm., 352, 280-286 (2008).

72) B. S. X. Teo, M. Basri, M. R. S. Zakaria, A. B. Salleh, R. N. Z. R. A. Rahman, A. M. B. Rahman; A potential tocopherol acetate loaded palm oil esters-in-water nanoemulsions for nanocosmeceuticals. J. Nanobiotech., 8, 1-12 (2010).

73) C. P. Liang, M.F. Wang, J. E. Simon, C. T. Ho; Antioxidant activity of plant extracts on the inhibition of citral off-odor formation. Mol. Nutr. Food Res., 48, 308-317 (2004).

74) S. J. Choi, E. A. Decker, L. Henson, L. M. Popplewell, D. J. McClements; Inhibition of citral degradation in model beverage emulsions using micelles and reverse micelles. Food Chem., 122, 111-116 (2010).
75) L. Mei, S. J. Choi, J. Alamed, L. Henson, M. Popplewell, D. J. McClements, E. Decker; Citral stability in oil-in-water emulsions with solid or liquid octadecane. J. Agric. Food Chem., 58, 533-536 (2010).

76) R. Engel, H. Schubert; Formulation of phytosterols in emulsions for increased dose response in functional foods. Innov. Food Sci. Emerg. Technol., 6, 233-237 (2005).

77) W. F. Leong, Y. B. Che Man, O. M. Lai, K. Long, M. Misran, C. P. Tan; Optimization of processing parameters for the preparation of phytosterol microemulsions by the solvent displacement method. J. Agric. Food Chem., 57, 8426-8433 (2009).

78) W. F. Leong, O. M. Lai, K. Long, Y. B. Che Man, M. Misran, C. P. Tan; Preparation and characterisation of water-soluble phytosterol nanodispersions. Food Chem., 129, 77-83 (2011).

79) C. S. Boon, Z. Xu, X. Yue, D. J. McClements, J. Weiss, E. A. Decker; Factors affecting lycopene oxidation in oil-in-water emulsions. J. Agric. Food Chem., 56, 1408-1414 (2008).

80) M. M. M. Affandi, T. Julianto, A. Majeed; Development and stability evaluation of astaxanthin nanoemulsion. Asian J. Pharm. Clin. Res., 4, 142-148 (2011).

81) I. Stratulat, M. Britten, S. Salmieri, D. St-Gelais, C. P. Champagne, P. Fustier, M. Lacroix; Encapsulation of coenzyme Q10 in a simple emulsion-based nutraceutical formulation and application in cheese manufacturing. Food Chem., 141, 2707-2712 (2013). 


\title{
食品機能性成分含有マイクロ ナノエマルションの作製と特性評価
}

\author{
王政 ${ }^{1,2}, \operatorname{Marcos}$ A. Neves ${ }^{1,2}$, 礒田博子 ${ }^{1,2}$, 中嶋光敏 ${ }^{1,2, \dagger}$ \\ ${ }^{1}$ 筑波大学北アフリカ研究センター, ${ }^{2}$ 筑波大学生命環境
}

エマルションとは水一油のように，互いに混じり合 わない 2 種の液体で，一方が他の液体中に分散してい るもののことをいう。互いに混じらない水一油を乳化 剤の作用で細かい液滴として分散させる操作を乳化と いい，乳化する作用をもつ物質を乳化㓮という。同一 組成のエマルションに打いては，分散液滴径と液滴径 分布がエマルションの諸特性に大きく影響を与える. 分散液滴の液滴径が小さく，液滴径分布が狭くなるほ どエマルションの安定性が向上する.エマルションの 粒子径は通常 $0.01 \sim 100 \mu \mathrm{m}$ 程度であり，20〜 $200 \mathrm{~nm}$ 程度の微細な粒子径のエマルションはナノエマルショ ンとよばれている。水一油系エマルションを形成する 場合, 油滴が水に分散する水中油滴 $(\mathrm{O} / \mathrm{W})$ 型エマル ションと，水が油に分散する油中水滴（W/O) 型エマ ルションなどがあげられる。また，水中に分散してい る油滴がさらに水を内包しているような状態は Waterin-Oil-in-Water (W/O/W) 型エマルションといい, これに対して，油中に分散している水滴がさらに油相 に分散させた状態を Oil-in-Water-in-Oil（O/W/O) 型エマルションという。ナノエマルションは食品機能 性成分送達システム（FDS）やドラッグデリバリーシ ステム (DDS) として食品，医薬品，化粧品分野への
応用が検討されている，普段損取した食品は，消化管 で様々な消化液と混合し細かく分解され，体内に吸収 された後に主として生体膜における生体反応に関与す るが，摂食から吸収までの消化過程においては，O/W エマルション粒子として運搬されている. とくに，吸 収直前では，粒子サイズがナノメートル程度のナノエ マルションから混合ミセルまで粒子サイズが微細化す ると考えられている．混合ミセルへの機能性を有する 成分の取込率が高いことを体内吸収性が高いとみなせ る. ポリフェノール類やカロテノイド類を含む食品機 能性成分は, 健康の維持や病気の予防に有効であるこ とが知られているが，その多くは熱，光，酸素などに 対して不安定であり，また脂溶性のものが多いため, 生体利用性が低いのが現状である。エマルション化す ることで, 脂溶性の食品機能性成分の生体内への吸収 性が改善できると知られているが，ここで，近年，食 品機能性成分を含有するマイクロ／ナノエマルション の作製法の事例扎よびその特性評価について紹介する。

なお本稿は, Foods \& Food Ingredients Journal of Japan（FFI ジャーナル） 219 巻 4 号 312 - 323 頁 $(2014$ 年) に掲載された原稿を，許可を得て，英訳したもの である。

(受付 2015 年 8 月 5 日, 受理 2015 年 11 月 17 日) 